\title{
ЗАСТОСУВАННЯ ІНФОРМАЦЙНО-КОМУНІКАЦЙНИХ ТЕХНОЛОГІЙ В ОРГАНІЗАЦІЇ НАВЧАЛЬНОЇ ДІЯЛЬНОСТІ СТУДЕНТІВ ТЕХНОЛОГО-ПЕДАГОГІЧНИХ СПЕЦІАЛЬНОСТЕЙ
}

\begin{abstract}
У статті розкрито специфіку застосування інформаційно-комунікаційних технологій в організації навчальної діяльності студентів технолого-педагогічних спеціальностей. Розглянуті фактори покращення якості знань студентів у вивченні загальнотехнічних дисииллін із використанням інформаційно-комунікаиійних технологій, проблеми впровадження $i$ використання навчально-контролюючих комп 'ютерних програм у навчальному процесі та ймовірні шляхи їх розв'язання.

Ключові слова: інформачійно-комунікачійні технологї̈, технологічна освіта, навчально-контролюючі програми, організація навчальної діяльності, загально технічні дисиипліни.
\end{abstract}

Статья раскрывает специфику использования информачионно-коммуникационных технологий в организации учебной деятельности студентов технолого-педагогических специиальностей. Рассмотрены факторы улучшения качества знаний студентов при изучении общетехнических дисииплин с использованием информационно-коммуникачионных технологий, проблемы внедрения и использования обучающе-контролирующих компьютерных программ в учебном процессе и вероятные пути их решения.

Ключевые слова: информационно-коммуникационные технологии, технологическое образование, обучающеконтролирующие программы, организация учебной деятельности, общетехнические дисциплины.

This article explains the specific of the use of informative-communication technologies in organization tekhnologo-pedagogical specialities students' educational activity. The factors of improvement of students' quality knowledges are considered at the study of technical disciplines with the use of informative-communication technologies, problems of introduction and use of the educational and controlling computer programs in an educational process and possible ways of their decision.

Key words: informative-communication technologies, technological education, educational and controlling programs, organization of educational activity, technical disciplines.

Одним із пріоритетних напрямків процесу інформатизації сучасного суспільства $є$ інформатизація освіти [4]. Це процес забезпечення сфери освіти методологією та практикою розроблення й оптимального використання нових інформаційних технологій, що орієнтовані на реалізацію психолого-педагогічних цілей навчання. Головними завданнями інформатизації освіти є: 1) створення методичних систем навчання, зорієнтованих на розвиток інтелектуального потенціалу студента, на формування вміння самостійно здобувати знання, використовувати різноманітні види самостійної діяльності з оброблення інформації; 2) створення та використання комп'ютерних тестових i діагностичних методик контролю й оцінювання рівня знань студентів.

Інформатизація вищих навчальних закладів є невід'ємним складником інформатизації освіти. Вона зумовлює необхідність перегляду попередніх й розробку нових форм, змісту, методів управління навчально-пізнавальною діяльністю студентів. Це дає змогу вдосконалити, полегшити роботу викладачів та студентів і, як наслідок, отримати якісно новий, кращий рівень знань. Доведено, що впровадження інформаційно-комунікаційних технологій у навчально-виховному процесі вищих освітніх закладів дає змогу посилити активізацію навчальної діяльності [2]. Комп'ютер сприяє підвищенню інтересу до навчання.

Проаналізувавши рівень розповсюдження і використання інформаційно-комунікаційних технологій у навчально-виховному процесі вищих навчальних закладів, ми з'ясували, що інформаційно-комунікаційні технології використовуються здебільшого для вивчення безпосередньо комп’ютера та стандартного пакета комп'ютерних програм. Отже, не здобули широкого розповсюдження у вивченні інших дисциплін. В організації навчальної діяльності студентів технолого-педагогічних спеціальностей інформаційно-комунікаційні технології майже не використовуються. Тому виникає необхідність розкрити умови й специфіку використання інформаційно-комунікаційних технологій саме в організації навчальної діяльності студентів технолого-педагогічних спеціальностей. Це дасть змогу пришвидшити, удосконалити й полегшити процес вивчення загальнотехнічних дисциплін і водночас ефективно, швидко й неупереджено провести тестовий контроль якості знань студентів.

Мета статmi - розкрити умови й специфіку використання інформаційно-комунікаційних технологій в організації навчальної діяльності студентів технолого-педагогічних спеціальностей: 1) розглянути чинники покращення якості знань студентів при вивченні загальнотехнічних дисциплін 3 використанням інформаційно-комунікаційних технологій; 2) висвітлити проблеми впровадження і використання навчально-контролюючих комп'ютерних програм у навчальному процесі та ймовірні шляхи їх розв'язання.

Нині вищі навчальні заклади мають необхідне матеріально-технічне забезпечення для реалізації завдань інформатизації освіти. Водночас упровадження інформаційно-комунікаційних технологій у навчальний процес на технолого-педагогічних спеціальностях потребує серйозної дослідницької 
роботи, від якої залежить успіх упровадження й успішного їх використання. Ця робота має розв'язати проблеми:

1) відбору змісту навчання, відповідно до нових напрямів освіти, ураховуючи дидактичні властивості та функції наявних технічних засобів і специфіку технологічної освіти;

2) впливу систем штучного інтелекту на характер мислення студентів і викладачів;

3) способи поєднання інформаційно-комунікаційних технологій 3 традиційними засобами навчання;

4) способи керування пізнавальною діяльністю студентів в умовах широкого інформаційнопредметного середовища.

Специфіка навчального процесу під час оволодіння технолого-педагогічними спеціальностями полягає в тому, що програмно-методичне забезпечення на основі інформаційно-комунікаційних технологій повинно включати, як програмні засоби для підтримки викладання, так і інструментальні програмні засоби, що надають змогу викладачу керувати навчальним процесом, його раціональною організацією.

Комп'ютерне навчання є потужним засобом інтенсифікації навчального процесу, але будь-які навчальні комп'ютерні програми, навіть виключно інформаційно-довідкового характеру, повинні в обов'язковому порядку перевірятися на їх власну педагогічну доцільність.

Нині великого значення набуває використання комп'ютера на етапі тестування й корекції знань студентів. У сучасних умовах, коли розроблення й тиражування навчальних і контролюючих програмних продуктів стає предметом бізнесу, ринок заповненій досить різноманітною різноплановою продукцією, виявлення критеріїв якості цієї продукції та її вибору набуває все більшої актуальності. Часто критеріями такої оцінки є винятково технічні характеристики програмних продуктів, не пов'язані безпосередньо з педагогічними й методичними умовами їх створення. Якість графічного дизайну, надійність, наявність і якість документації та інше - усі ці критерії, безумовно, важливі, але, на нашу думку, не вони визначають основних характеристик програмних продуктів, призначених для використання їх безпосередньо в навчальному процесі.

Слід зазначити, що використання інформаційно-комунікаційних технологій в навчальному процесі при вивченні загальнотехнічних дисциплін зумовлює докорінні структурні і функціональні зміни навчальної діяльності. Трансформується ії виконавча будова, просторово часові параметри взаємодії суб'єкт-суб'єкт, й суб'єкт-інформаційне середовище, комунікаційні компоненти діяльності, ії вимоги, мотиваційна регуляція та інше.

Ми вважаємо, що використання інформаційно-комунікаційних технологій може розв'язати проблему вдосконалення процесу вивчення загальнотехнічних дисциплін за рахунок збільшення активного часу кожного студента, що відводиться на навчання, посилення наочності та моделювання ситуацій, які необхідно розглянути в процесі навчання. Практика показує, що впровадження інформаційно-комунікаційних технологій в освітній процес технолого-педагогічних спеціальностей передбачає їх використання, передовсім,у вивченні саме загальнотехнічних дисциплін, які $\epsilon$ головною компонентою технологічної освіти.

Спостереження доводять, що в умовах діалогу з комп'ютером студент формує такі узагальнення, образи, моделі, на які не здатен в умовах взаємодії з іншими людьми чи індивідуально. Крім того, потрапивши в нове інформаційне середовище, студент може ставити більш оригінальні, творчі та значною мірою більш змістовні цілі.

Як наслідок, сукупність цих змін дозволяє говорити про використання інформаційнокомунікаційних технологій в навчальному процесі як-от: новий специфічний вид діяльності «Розвивальне середовище», що вміщує в собі властивості пізнавальної, комунікативної, ігрової, розумової та творчої діяльності. Більш повне, глибоке управління безпосередньо навчальним процесом.

Отже, використання інформаційно-комунікаційних технологій у вивченні загальнотехнічних дисциплін призводить до якісної своєрідної навальної діяльності.

Процес вивчення загальнотехнічних дисциплін із використанням інформаційно-комунікаційних технологій порівнянно 3 традиційним навчанням має такі переваги: а) скорочується час, який витрачається на засвоєння навчального матеріалу (за оцінками спеціалістів, використання комп'ютерних навчально-контролюючих програм у 1,5-2 рази скорочує час засвоєння навчальних предметів); б) завдяки використанню комп'ютерних технологій виникають принципово нові підходи до підвищення інформаційності навчальних курсів; в) комп’ютер забезпечує навчання, яке $\epsilon$ адаптованим до потреб конкретного студента.

На практиці виявилося, що досягти значного підвищення ефективності навчального процесу 3 використанням інформаційно-комунікаційних технологій можливе лише за умови наявності якісних спеціально розроблених навчально-контролюючих комп'ютерних програм.

Тому наступним етапом впровадження інформаційно-комунікаційних технологій у навчальний процес, на нашу думку, має бути розроблення й упровадження навчально-контролюючих програм на рівні з іншими формами і методами навчання та контролю знань студентів. 
Характерною особливістю навчально-контролюючих програм $є$ інтеграція в одному програмному продукті різноманітних видів інформації, як традиційних (текст, таблиці, ілюстрації тощо), так і нетрадиційних (мова, музика, відео, анімація тощо).

Найбільш розповсюдженими нині $є$ навчально-контролюючі програми лінійного й розгалуженого характеру. У перших програмах після порції матеріалу пропонується перевірочне завдання. Якщо студент виконує його, то надається наступна порція матеріалу. Логіка навчання має лінійний характер. Метою таких програм є попередження помилок студентів. В іншому випадку після вивчення порції інформації також пропонується завдання, але до нього додається кілька варіантів відповідей один 3 яких $\epsilon$ правильним, а інші- помилкові. Якщо студент обирає неправильну відповідь то отримає в черговому кадрі пояснення допущеної помилки, й повертається до вихідного кадру. Ми вважаємо що такий варіант навчально-контролюючих програм, більшою мірою адаптований до індивідуальних особливостей студентів, й підходить для впровадження в навчальний процес.

Програми розгалуженого характеру дозволяють реалізувати такі методичні цілі навчання як: повідомлення інформації для навчальної діяльності;

наочна демонстрація навчального матеріалу;

індивідуалізація й диференціація процесу навчання;

реалізація діалогу з комп’ютером;

контроль зі зворотнім зв'язком та оцінкою результатів;

надання індивідуальних завдань для самостійної роботи.

Найбільш ефективним виявився такий варіант навчально-контролюючої програми, яка $\epsilon$ комплексом двох основних видів програм: комп'ютерний підручник для самостійного засвоєння дисципліни та тестову контролюючу програму для оцінювання знань студентів. Тестова система спонукає студента працювати системно й інтенсивно та дозволяє якісно змінити контроль знань студентів, які самостійно можуть обирати необхідну допомогу електронного підручника в разі виникнення потреби.

Під час проведення дослідження виявилося, що майже усі чинні навчально-контролюючі програми $\epsilon$ або досить складними у використанні, що обмежує їх застосування серед студентів зі слабкою комп’ютерною підготовкою, або розроблені безпосередньо для певного (конкретного) предмета, що обмежує їх використання у вивченні інших предметів.

Під час розроблення навчально-контролюючих програм необхідно домагатися максимального спрощення спілкування студентів 3 комп'ютером, оскільки більшість студентів ознайомлена 3 комп'ютером не належним чином. Тому в розробленні навчально-контролюючих програм 3 загальнотехнічних дисциплін ми, передовсім, керувалися принципами доступності знань й обрали програми, нескладні у використанні: текстовий редактор Microsoft Word та програму тестування «Асистент».

Навчальна частина програми включає електронний варіант лекційного матеріалу, доступ до якого студент має у будь-який зручний для нього час. Зручний і простий інтерфейс текстового редактору Microsoft Word, у якому подано електронний варіант лекцій, дозволяє користуватись інформацією навіть тим студентам, які слабко підготовлені до роботи з комп'ютерною технікою, а також надає змогу відтворити будь-який фрагмент на папері. Це сприятиме тому, аби студенти самостійно готуватися до лекцій і опрацьовувати необхідний матеріал у випадку «прогалин» у знаннях.

Контролюючу частину програми було обрано через порівняльний аналіз різних програмних продуктів. Нашою метою було знайти серед них такий, що за мінімальної вартості й мінімальному розмірі дискового простору, що займає програма у постійній пам'яті комп'ютера, забезпечував би максимальну функціональність, широту налаштувань, режимів роботи, простоти користування й створення тестів.

Ми порівнювали такі програми: 1. «Конструктор тестов 2.5» від компанії Keepsoft, автор Павло Козловський; 2. «TEST-W», автор Шестопалов Олексій; 3. Контролююча програма «Test», автор студент технолого педагогічного факультету КДПУ Іванча Антон; 4. Програмний комплекс «ElBook» що містить «ModelMaker», «TaskMaker», «LessonMaker», автор студент фізико математичного факультету КДПУ Кравченко Володимир; 5. «Assist2» (Асистент II), автор Іваненко Федір.

«Конструктор тестов 2.5» має такі можливості: використання необмеженого числа тем, питань i відповідей, питання можуть містити зображення (файли jpg, bmp, ico, emf); можливість ставити питання в довільному порядку, обмежити відповіді за темою за часом, виставляти оцінку після завершення тестування, система оцінок налаштовується в «Редакторі», шкалу оцінок можна налаштувати від 5-бальної до 100-бальної системи. Водночас, вона має такі недоліки: великий розмір програми на установочному диску (317 МБ), програма потребує установки на комп'ютер і не може бути скопійованою $з$ одного комп'ютера на інший, для створення нового тесту використовується окремий додаток, програмою не можна користуватися безкоштовно. Для використання програми необхідно придбати ліцензію.

Контрольно-діагностична система TEST-W має такі переваги: малий розмір на диску (2.4 МБ), програма не потребує встановлення і легко копіюється з одного комп'ютера на інший, має зручний і 
простий інтерфейс, програма є бе-зкоштовною у використанні й тиражуванні. Водночас, ми вважаємо вона має i низку недоліків, а саме: обмежене коло налаштувань. Налаштовувати можна лише кількість запитань, що будуть заданими та час, відведений на відповіді, неможливо додати до запитання малюнок чи схему, програма оцінює відповіді лише за 12-ти бальною шкалою, неможливо по завершенню тесту з'ясувати, які відповіді були неправильними.

Контролююча програма «Test» $\epsilon$ власною розробкою кафедри загальнотехнічних дисциплін Криворізького педагогічного університету. Програму написано з використанням Borland Delphi 6.0 для контролю знань студентів із дисципліни «Автосправа». Робота 3 програмою починається 3 перегляду короткого відеоролика, після чого студент має відповісти на запропоновані запитання. Основні можливості програми: підтримка малюнків, випадкове виведення запитань на екран, виведення в кінці тесту кількісного відношення правильних і помилкових відповідей, оцінюючи проаналізовану програму, ми вважаємо позитивним те, що був створений власний програмний продукт. Проте нині він не є ідеальним і має недоліки: вузьке коло налаштувань, немає обмеження часу відповіді на запитання, складна система створення нового тесту, тестування можливе тільки 3 одної дисципліни.

Програмний комплекс «ElBook» призначений для створення електронних посібників i $\epsilon$ узагальненням універсальних систем тестування. Випробувавши даний комплекс, ми виявили недоліки, які не дозволяють його використовувати під час вивчення загальнотехнічних дисциплін, а саме: до його складу входить пакет окремих програм, що значною мірою ускладнюють процес використання, великий розмір програми на установочному диску (60.8 МБ), неможливо ставити запитання у випадковому порядку.

«Assist2» (Асистент II) призначена для контролю знань студентів за допомогою персонального комп'ютера. Можливі два режими роботи: контроль знань (з усіх доступних питань обирається вказана викладачем кількість), тренажер (програма ставить усі доступні питання). При запуску програми викладач може: ставити запитання у випадковому порядку, обмежити час відповіді на питання, програма зберігає статистику роботи з кожного питання в режимі реального часу, підтримує виведення матеріалу, що вивчається. Проаналізувавши подану програму, зазначимо, що вона має великий перелік якостей, які позитивно ії характеризують, а саме: дуже малий розмір на диску (0.5 МБ), не потребує встановлення, легко копіюється з одного комп'ютера на інший; має широке коло налаштувань i можливостей, зручний інтерфейс; підтримує використання малюнків, вивід теоретичного матеріалу перед початком тесту; створювати нові тести для програми легко і зручно без використання інших додатків, надійно зберігає статистику тестування, програма є безкоштовною для використання. Під час іiі випробовування й експериментального використання викладачами кафедри програма працювала стабільно.

Беручи за основу результати порівняльного аналізу контролюючих програм, можна зробити висновок, що для контролю знань студентів із використанням комп'ютерів у вивченні загальнотехнічних дисциплін найбільш ефективною є «Assist2» (Асистент II). Отже, на базі редактора Microsoft Word i програми Асистент II було створено навчально-контролюючі програми 3 таких загальнотехнічних дисциплін: деталі машин, теплотехніка, опір матеріалів, нарисна геометрія i креслення, основи взаємозаміни та ін.

Перевагами наведених навчально-контролюючих програм слід уважати простоту у використанні, завдяки зручному інтерфейсу Windows та вивід на екран запитань тесту випадково у хаотичному порядку, що попереджує можливість знання відповідей заздалегідь. Зручний автозміст текстового редактора Microsoft Word дозволяє швидко перейти до потрібної теми і за необхідності роздрукувати інформацію за допомогою принтера на папір. Отже, використання навчально-контролюючої програми дозволяє активно залучати студентів до учбового процесу, значно покращити засвоєння знань, а також надає можливість контролю ефективності їх засвоєння в умовах кредитно-модульної системи навчання.

Використання інформаційно-комунікаційних технологій під час вивчення загальнотехнічних дисциплін (за умови використання спеціально розроблених навчально-контролюючих комп'ютерних програм) зумовлює більш якісну навчальну діяльність у порівнянні 3 традиційними методами навчання. При цьому змінюється мотиваційна компонента. Пізнавальна активність і діяльність стає більш особистісною, індивідуалізованою і вільною від впливів різних психологічних бар'єрів, посилюючи вплив мотивів саморозвитку і самореалізації студента, невілюючи побічні для змістовної сторони пізнання фактори (зниження захисної мотивації, мотивації соціально-престижного характеру, соціальних, вікових, статевих, індивідуально-особистісних, рольових та інших особливостей студентів).

Досвід застосування навчально-контролюючої програми у вивченні загальнотехнічних дисциплін свідчить про підвищення ефективності підготовки вчителів в умовах входження до Свропейського освітянського простору.

\section{Література}

1. Воронин Т. П. Образование в эпоху новых информационных технологий / Т. П. Воронин, В. П. Кашица. М., 1995. - 443 с. 2. Завізена Н. Комп'ютеризація освіти з точки зору психолого-педагогічного аспекту / Н. Завізена // Рідна школа. - 1999.- № 11. - С. 62. 3. Оспенникова Е. В. Современная образовательная среда и 
методы обучения / Е. В. Оспенникова // Школьные технологии. - 2002. - № 4. - С. 24-35. 4. Полат Е. С. Интернет в образовании / Е. С. Полат. - М., 2001. 5. Питюков В. Ю. Основы педагогической технологии / В. Ю. Питюков. - М., 1997. - С. 6-11. 